Permanently Frozen Soil (Instituta Merzlotovedeniya). The Institute's workers have achieved success in keeping open the railroads of the Norilsk industrial region, which is subject to a lengthy period of strong winds and drifting snow. Attention has also been given to the use of snow as a building material-and this has been applied to the construction of snowhouses for the Red Army and also to the development of ice warehouses as a cheap and effective form of cold storage. Methods have been evolved to avoid the freezing of soil which has so far made it difficult to reach valuable mineral deposits in mine workings. The Institute has also given advice for the provision of water supplies for the cities of Yakutsk and Irkutsk by constructing artesian wells to tap the water below the frozen strata.

Workers from the Institute have also been sent to the Transbaikal and Norilsk regions to advise on the intricate building problems which arise in areas of frozen soil. In certain cases buildings are designed to prevent the subsoil from thawing. In others the subsoil is thawed out electrically and prevented from re-freezing.

\title{
RESUMPTION OF THE NORTH ATLANTIC INTERNATIONAL ICE PATROL AND ICE OBSERVATION SERVICE, 1946
}

[Based on notes in the Hydrographic Bulletin (Washington), March-June 1946, and the Christian Science Monitor, 22 March 1946.]

By Presidential Order, the International Ice Patrol and Ice Observation Service will be resumed during the ice season of 1946 . The patrol will be conducted by the United States Coast Guard. The force assigned will carry out the provisions of the International Convention for the Safety of Life at Sea, London, 1920, relating to ice observation, ice patrol, and derelict destruction.

The object of the Ice Patrol Service is to locate, by scouting and radio information, the icebergs and ice fields nearest to and menacing the North Atlantic shipping routes. The Patrol vessels will determine the south-eastern, southern, and south-western limits of the iceberg area in the vicinity of the Grand Banks of Newfoundland and keep in touch with it as it moves southward in order that radio broadcasts may be transmitted daily giving locations of ice, particularly in the immediate vicinity of the North Atlantic routes

Throughout the ice season, Radio Washington will broadcast daily iceinformation bulletins. Summaries of this information will be repeated locally from Boston, New York, and Norfolk. Radio Argentia, Newfoundland, will broadcast two daily Ice Bulletins for the benefit of shipping. Patrol vessels will maintain a continuous listening watch for distress signals. A continuous watch will also be maintained for general communications, such as ice and watertemperature reports and requests for additional information about Ice Broadcasts which may have been missed.

The United States Coast Guard cutters engaged on Ice Patrol duty hope to receive information by radio from steamships concerning icebergs and sea- 
water surface temperatures between latitudes $39^{\circ}$ and $49^{\circ} \mathrm{N}$. and between longitudes $43^{\circ}$ and $56^{\circ} \mathrm{W}$. This information will facilitate the drawing of temperature curves which will be useful in locating the branches of the Labrador Current.

This year for the first time the United States Coast Guard cutters which undertake the patrol will use radar to locate icebergs at night and in fog. B-24 aircraft will also be employed to make air surveys of sea ice, growlers and icebergs. Both aircraft and cutters will be based on Argentia, Newfoundland, headquarters of the International Ice Patrol. Rear-Admiral Earl Griffith Rose, United States Coast Guard, has been appointed Commander of the North Atlantic Ice Patrol.

\section{UNITED STATES ARCTIC METEOROLOGICAL STATIONS}

[We print below the text of United States Public Law 296-70th Congress, Chapter $\downarrow$ 2nd Session. S. 765.]

$$
A N A C T
$$

Concerning the establishment of meteorological observation stations in the Arctic region of the Western Hemisphere, for the purpose of improving the weather forecasting service within the United States and on the civil international air transport routes from the United States.

Be it enacted by the Senate and House of Representatives of the United States of America in Congress assembled. That in order to improve the weather forecasting service of the United States and to promote safety and efficiency in civil air navigation to the highest possible degree, the Chief of the Weather Bureau, under the direction of the Secretary of Commerce, shall, in addition to his other functions and duties, take such action as may be necessary in the development of an international basic meteorological reporting network in the Arctic region of the Western Hemisphere, including the establishment, operation, and maintenance of such reporting stations in co-operation with the State Department and other United States governmental departments and agencies, with the meteorological services of foreign countries and with persons engaged in air commerce.

Sec. 2. There are hereby authorized to be appropriated such sums as may be necessary to carry out the provisions of this Act.

Approved February 12, 1946.

\section{SOVIET METEOROLOGICAL STATION ON VIZE ISLAND}

[Based on a note in Soviet News, No. 1292, 1 November 1945.]

In September 1945 Professors Tikhomirov and Goltsman of the Arctic Institute, with six others, established a meteorological station on Vize Island, which is situated midway between Franz Joseph Land and Severnaya Zemlya. The existence of this island was first suspected in 1924 by Professor Vladimir Vize 